This is an Accepted Manuscript of an article published by Taylor \& Francis in Production Planning \& Control on 3 Nov 2020, available online: https://www.tandfonline.com/doi/full/10.1080/09537287.2020.1843081

\title{
Managing strategic resources in petroleum industry projects
}

\author{
Moosa Ali Mas'oud Al-Hanshi \\ University of Hull \\ Udechukwu Ojiako \\ University of Sharjah \\ University of Hull \\ Nnamdi Azikiwe University \\ Terry Williams \\ University of Hull
}

\begin{abstract}
This paper seeks to explore how strategic resources in petroleum industry projects are to be best managed and exploited in order deliver enhanced project performance and sustained business competitiveness. Framed upon the Resource-Based View ('RBV') theory, these resources should be 'Valuable', 'Inimitable', 'Rare' and be able to draw on 'Organizational support' ('VIRO'). Qualitative data were collected from petroleum industry organizations operating in the United Arab Emirates and the Sultanate of Oman between 2017 and 2019. Analysis shows that at the project level, 'Value' and 'Organizational support' attributes of resources were positively related to competitive advantage and both impacted by dynamic capabilities and innovative environment. However, the 'Rareness' and 'Inimitability' attributes showed less evolution. We also find that at the project level, the main characteristics of organizational resources were that they are 'Valuable', 'Organizationally
\end{abstract}


supported', and that they could be 'Uniquely exploited' while being 'Readily available'. The results suggest a desire by project-oriented organizations to replace the 'Rareness' and 'Inimitability' attributes within VIRO with two alternative attributes, namely 'Unique exploitation' and 'Timely availability' of resources.

\subsection{Introduction}

\subsection{Study context}

Our study is being driven by an appreciation that the petroleum industry is facing major economic difficulties driven by a number of external factors including fluctuations in oil prices. Currently, these challenges have been largely driven by oil price disputes between Russia and Saudi Arabia and the Coronavirus disease (COVID-19) pandemic. The implication is that petroleum companies are being challenged to reduce operating and capital budgets associated with their various projects (spanning drilling, exploration, and reservoir management) while at the same time, they are expected to maintain the same level of oil and gas production (at lower cost) in order to shore up profit margins. Thus, for example, over the last three years, the Petroleum Development Oman (the major oil production company in the Sultanate of Oman and among the largest in the Arabian Gulf region), has initiated an aggressive US\$1.5 billion cost-cutting policy. This initiative has entailed a complete revisit and re-evaluation of not only all its ongoing capital projects, but also all projects currently at conceptualization and tender stage (Petroleum Development Oman 2017). Examples of such projects includes a 45,000 barrel per day (b/d) gas-to-liquid project to be operated by Royal Dutch Shell PLC, which is currently at design stage (McQue 2020). An unintended consequence of these cost-cutting initiatives is that the integrity of 
organizational resources will be interfered with. Yet, some of these resources are not only extremely indispensable to project performance, but also organizational competitiveness.

\subsection{Resources and the Resource-Based View ('RBV') theory}

The Resource-Based View ('RBV') theory is "...one of the most prominent and powerful theories for understanding organizations" (Barney et al. 2011, p. 1299). It also represents one if not the single most important theory utilized to facilitate understanding of the origins of both superior performance and competitive advantage (Bingham and Eisenhardt 2008). The core thesis of this theory is that to achieve superior performance and ultimately, gain competitive advantage, an organization must maintain 'routines' that are specialized and also 'resources' that are superior and exhibit certain specific attributes. RBV theory is particularly focused on resources deemed 'strategic' in nature. These are resources deemed to be characterized by specific attributes, namely; 'Valuable', 'Inimitable', 'Rare' and able to draw on 'Organizational support' ('VIRO'). Essentially, the theory posits that while organizations can achieve short-term superior performance and competitive advantage by for example simply focusing on routines which brings about functional differences with other organizations (Prahalad and Hamel 1990; Grant 1991; Mahoney and Pandian 1992; Petrick et al. 1999), long term and sustained performance and competitive advantage requires organizations to effectively and efficiently leverage and exploit relevant strategic resources (see Barney's work - see references below). In this context, 'routines' refers to carefully crafted multi-level actions utilized to achieve a specific objective (see Zimmermann et al. 2015). 'Resources' refers to "...organizational level factors that have the potential to contribute economic benefit" (Galbreath 2005; p. 980). Barney (1991) on the other hand defines 'resources' as “...all assets, capabilities, organizational processes, firm attributes, 
information, knowledge, etc. controlled by a firm that enable the firm to conceive of and implement strategies that improve its efficiency and effectiveness" (p. 101).

\subsection{RBV theory and project level analysis}

Our study is rooted on the premise that RBV theory will serve as an appropriate lens to explore how strategic resources in petroleum industry projects are to be best managed and exploited in order deliver enhanced project performance and sustained business competitiveness. In particular, we focus on the lack of a clear articulation in the literature of how this macro-problem of performance and competition filters up the organization from the 'project level' to the 'strategic level' and/or 'institutional level'. We do so taking cognizance of the associated tensions flowing from resource heterogeneity. Drawing from Petro et al. $(2019,2020)$, we opine that while the main decisions on strategic resources are made at the strategic or institutional level, due to the susceptibility of core organizational rigidities at this level (as a result of process rigidities), it is at the 'project' level' and not the 'strategic level' and/or 'institutional level' that the accrued benefits from resources are realized. Projects incorporate strategic resources that can provide the umbrella organization a unique position and, accordingly, sustain competitive advantage over its competitors. In effect, the project becomes a source of competitive advantage for the organization. We will further be arguing that there is a paucity of 'project level' RBV research.

Our focus on resources on the 'project level' is also part of long standing developments in operations management research which has become more granular and increasingly shifted its focus to 'project level' (this is a long literature, including Buffa 1980; Rolstadas 1994, 1999; Bryde 2003; Kavadias 2014; Maylor et al. 2018; Zwikael and Meredith 2018). More specifically, Kavadias (2014) states that “...we should expect more studies to 
analyze decisions and phenomena at the project level" (p. 1261). Insights generated from such studies are particularly important in that they are able to facilitate an understanding of the interrelationship between the decisions taken within sub-units of an organization and their associated supporting processes (Bashir et al. 2020).

\subsection{The research question}

A point worth noting is that the problem of ensuring that RBV theory provides the necessary guidance on how performance and competitive success can filter down from the strategic level and institutional level to the project level makes demands for connections to be established between the various levels in a manner which will facilitate resource alignment. Such an understanding is important as it is inevitable that tensions will exist between these different levels (Chandrasekaran et al. 2012), and not managing these tensions is a major source of risk to enhanced project performance and sustained business competitiveness (Marshall et al. 2019; Al-Mazrouie et al. 2020). Organizations will generally consist of different stakeholders which research should not treat as cohesive or homogeneous decision making units (Ojiako et al. 2014, 2015; Chipulu et al. 2019). However, these tensions require management despite the reality that practitioners across different levels of an organization are likely to continue to maintain informal and professional ties that last well beyond the completion of a specific project. With this in mind, we present our research question as:

$R Q:$ What are the strategic resources available in projects and how do these strategic resources provide for enhanced project performance and sustained business competitiveness? 
To address this question, we structure the remainder of the paper in the following manner. In the next section (section 2), we articulate the key concepts to this study. In Section 3, we review and outline the literature on RBV theory while in Section 4, we discuss how the RBV is applied at the project-level; in the process, we articulate how the macro-problem of performance and competition filters down the organization hierarchy to the project level. Section 5 describes the research methods. Findings are presented in Section 6 while conclusions are drawn in Section 7.

\subsection{Key concepts}

There are a number of key concepts that underlie RBV theory that require our articulation. An example of such a concept is 'project-oriented organization' which we use to denote companies and business entities where not only is a significant part of their operations organized around projects, but also “... where project management and, more broadly speaking, project competence is at the heart of their competitive posturing" (Söderlund 2005. p. 453). We define 'Dynamic capabilities', drawing from Teece et al. (1997), as "...the firm's ability to integrate, build, and reconfigure internal and external competences to address rapidly changing environments" (p. 516). In this context, the term 'Dynamic' refers to the capacity of renewing competences in order to achieve congruence with the changing business environment". The academic literature suggests that 'Dynamic capabilities' are a mediating factor between resources and performance ( $\mathrm{Wu}$ 2007). Other terms include 'Competitive advantage', which Fahy (2000) defines as “...an advantage one firm has over a competitor or group of competitors in a given market, strategic group or industry" (p. 96) 
and 'Sustainability' which is used to reflect the concept of an organization's long-term survival in the market (Cabrer-Borrás and Rico Belda 2017).

The term 'Performance' is ambiguous (Otley 2003). It is a concept not defined by any form of action, but by a process of evaluation and judgement of the consequence of such action. Our reference to 'Project performance' implies both 'effectiveness' and 'efficiency'. Drawing from the literature (see Neely et al. 1995), 'effectiveness' implies the ability of a project to successfully deliver an output or effect. On the other hand, 'efficiency' implies the ability of a project to deliver outputs without resource waste.

RBV theory posits the 'heterogeneity' of strategic resources, which means that organizations possess different resources and capabilities to compete against each other (Peteraf and Barney 2003). In effect, the way these resources are utilized are different from one organization to other, although they are all competing in the same market or industry. Accordingly, this implies that some organizations are more capable of creating unique strategies and implementing those strategies using unique combinations of resources and capabilities than other organizations (Barney 1995; Barney et al. 2011).

\section{The literature}

\subsection{Historical development of RBV theory}

The antecedents of RBV theory go back to over 70 years ago to Penrose (1959) who stressed the importance of a firm's resources as a factor for its growth. Lippman and Rumelt (1982) added two main concepts to Penrose's (1959) original concept, the 'Inimitability' of resources and 'Causal ambiguity'. Here, 'Inimitability' means that for an organization's resources to lead to competitive advantage, they must be very hard for other firms to copy or replicate. 'Causal ambiguity', on the other hand, means that the complex relationship 
between the resources exploited by the organization and the performance of the organization cannot be easily understood. RBV theory was shaped later, in the 1980s, although popularized by Barney $(1991,1995)$. In Table 2, we show the development of the RBV literature.

Table 1: Historical development of RBV

\begin{tabular}{|c|c|c|c|c|c|}
\hline $\begin{array}{l}\text { Aspect / } \\
\text { Reference }\end{array}$ & $\begin{array}{l}\text { Penrose } \\
\text { (1959) }\end{array}$ & $\begin{array}{l}\text { Lippman and } \\
\text { Rumelt (1982) }\end{array}$ & $\begin{array}{l}\text { Wernerfelt } \\
\text { (1984) }\end{array}$ & Barney (1995) & $\begin{array}{l}\text { Teece et } \\
\text { al.(1997) }\end{array}$ \\
\hline $\begin{array}{l}\text { The } \\
\text { developmen } \\
\text { t of RBV }\end{array}$ & $\begin{array}{l}\text { The first is } \\
\text { a } \\
\text { collection } \\
\text { of } \\
\text { resources }\end{array}$ & $\begin{array}{l}\text { added two main } \\
\text { concepts to the } \\
\text { resource-based } \\
\text { theory, which } \\
\text { are inimitability } \\
\text { of the resources } \\
\text { and causal } \\
\text { ambiguity }\end{array}$ & $\begin{array}{l}\text { The organization } \\
\text { should } \\
\text { concentrate } \\
\text { more on } \\
\text { resources } \\
\text { compared with } \\
\text { products to gain } \\
\text { the competitive } \\
\text { advantage }\end{array}$ & $\begin{array}{l}\text { The firm gained } \\
\text { competitive } \\
\text { advantage by } \\
\text { exploiting rare, } \\
\text { valuable, hard to } \\
\text { copy resources }\end{array}$ & $\begin{array}{l}\text { The firm gained } \\
\text { competitive } \\
\text { advantage by } \\
\text { exploiting rare, } \\
\text { valuable, hard to } \\
\text { copy resources } \\
\text { using unique } \\
\text { dynamic } \\
\text { capabilities }\end{array}$ \\
\hline
\end{tabular}

\subsection{RBV theory}

In its current form, RBV theory was first proposed by Barney (1991) and extended in his later works (see for example, Barney and Zajac 1994; Barney 1995, 1996, 1999, 2001a, 2001b, 2001c, 2018; Barney et al. 2001, 2011). RBV theory is quite mature having over the last few years undergone considerable evolution and development (see Table 2). Thus, over the years, different terminology has been used to describe its attributes. These terms include 'Valuable', 'Rare', 'Inimitable' and 'Non-substitutable' or 'Non-transferable' (Barney 1991; Wade and Hulland 2004), 'Appropriable' (Wade and Hulland 2004), and 'Immobile' (Wade and Hulland 2004), 'Heterogeneous' (Barney 1991), 'Durable' (Priem and Butler 2001a, 2001b; Jugdev and Thomas 2002), and 'Organizationally focused' (Priem and Butler 2001a, 2001b; Jugdev and Thomas 2002). 
Table 2: Summary of evolution and development of the RBV

\begin{tabular}{|c|c|c|c|c|}
\hline $\begin{array}{l}\text { Aspect / } \\
\text { Reference }\end{array}$ & Penrose (1959) & Barney (1995) & Teece et al. (1997) & $\begin{array}{l}\text { Barney and Clark } \\
\text { (2007) }\end{array}$ \\
\hline $\begin{array}{l}\text { What is RBV } \\
\text { focused on }\end{array}$ & $\begin{array}{l}\text { The firm is a } \\
\text { collection of } \\
\text { resources which } \\
\text { are needed for } \\
\text { the firm growth } \\
\text { and it is the } \\
\text { heterogeneity } \\
\text { of those } \\
\text { resources that } \\
\text { gives a firm its } \\
\text { special } \\
\text { character }\end{array}$ & $\begin{array}{l}\text { For any organization to } \\
\text { have a sustained } \\
\text { competitive advantage, } \\
\text { the management has to } \\
\text { look inside the } \\
\text { organization for their } \\
\text { unique and strategic } \\
\text { resources and } \\
\text { capabilities that are } \\
\text { valuable, rare, hard and } \\
\text { costly to imitate, and } \\
\text { then provide the } \\
\text { necessary support to } \\
\text { exploit them }\end{array}$ & $\begin{array}{l}\text { The firm needs to } \\
\text { establish a specific } \\
\text { characterization of } \\
\text { resources and exploit } \\
\text { those strategic } \\
\text { resources using } \\
\text { organizational dynamic } \\
\text { capabilities in order to } \\
\text { gain sustained } \\
\text { competitive advantage }\end{array}$ & $\begin{array}{l}\text { A firm can gain a } \\
\text { competitive } \\
\text { advantage when } \\
\text { other competing } \\
\text { firms are not able } \\
\text { to imitate the } \\
\text { benefits of its } \\
\text { strategy }\end{array}$ \\
\hline
\end{tabular}

\subsection{Tangible and intangible resources}

Resources can be classed into types. For example, resources can be classed based on their effect on performance ('ordinary' or 'junk') or based on their tangibility ('tangible' or 'intangible'). Thus, for example, Warnier et al. (2013) refers to other resources as 'ordinary', in other words, resources that are "...perceived by firms as neutral in terms of performance" (see Warnier et al. 2013, p. 1360) and/or as 'junk resources', that is resources "...perceived as negative in terms of performance" (see Warnier et al. 2013, p. 1360).

In terms of the 'tangible' and 'intangible' resource categorization, a resource is 'tangible' when it is associated with a physical value (Garcia-Parra et al. 2009). Generally, what is deemed a tangible resource is quite settled and has not attracted much controversy in the literature (Andersen and Kheam 1998). In a project context, tangible assets may refer to for example, project management bodies of knowledge. The other category of resources 
are termed 'intangible'. Kristandl and Bontis (2007; pp. 1518-1519), defines intangible resources as "...strategic firm resources that enable the creation of sustainable value which leads to future potential benefits which are neither appropriable, imitable, substitutable, transferable or tradeable". Intangible resources come in two forms in that they can be 'assets' or 'competencies' (Hall 1993). Assets are property with value to an organization while competencies are essentially, skills that encompass explicit and implicit knowledge. Resources which are intangible can attract an element of controversy. For example, a review of the literature suggests that intangible assets seem to be associated with different forms of classification (see for example Hall, 1992, 1993; Teece 1998; Fernandez et al. 2000; Kristandl and Bontis 2007). This is despite a view that claims that they cannot be readily observed, isolated or measured (Lev 2007). To other scholars such as Foss et al. (2008), what is distinct about intangibles is not their attributes, but the use they can be put to.

Intangible resources are characterized by three intriguing attributes that make them quite distinct from tangible resources. According to Molloy et al. (2011), these are (i) that they do not reduce, depreciate or degrade as they are being used; thus, for example, skills whatever the extent of use are never reduced, depreciated or degraded (ii) intangible resources can be used simultaneously (iii) their exchange is difficult in that they are not readily separated from their owner.

\subsection{Key attributes of RBV theory}

RBV theory addresses the characteristics needed for a resource to be considered 'strategic' in nature. At a very basic form, this requires resources to be 'Valuable', 'Inimitable', 'Rare', and 'Supported by the organization' ('VIRO'). 


\subsubsection{Valuable}

A resource is 'Valuable' when it enables an organization achieve lower costs compared with their competitors (De Massis et al. 2017) or when it provides an organization with many other products and services, and furthermore creates rent for the firm (Wang et al. 2013). Resources and capabilities can be designated as valuable if they have the potential to reduce costs, have the effect of acquiring market industry opportunities and neutralize the corresponding threats of other competitors. The amount of value gained depends on how effectively the organization deploys these valuable resources and capabilities to achieve competitive advantage. The value of a resource can be ascertained in monetary terms. An example in the petroleum industry will be the sale value of an operational asset such as a drilling tool. Using monetary terms to assess value allows the organization in question to follow-up on the value of such resources as they are purchased, used and discarded or sold.

\subsubsection{Rare}

A 'rare' resource simply means that the organization owns resources that are not commonly available to other players and competitors (Barney 1991; Bowman and Ambrosini 2003). If the resource is common and obtainable by most or all competitors, then competitive advantage cannot be achieved as other competitors can implement similar strategies and accordingly, reducing the firm's unique position in the market (Ashrafi and Mueller 2015). Rareness can mean applying, for example, common resources with rare capability (Newbert 2008). In the petroleum industry, an example of this is the use of the same drilling tool for drilling oil wells, but with different sets of well profiles and tool arrangements. The same goals can be achieved by exploiting the rare resource capability combination, reducing cost and responding to market opportunities and threats. An example of such rare resources are 
high quality human resources and skills in the form of cognitive ability. As Wright et al. (1994) observes, as there is a normal distribution of cognitive ability within the population, high quality human resources and skills in the form of cognitive ability is largely, rare. For that reason, organizations with a large talent pool of employees with high cognitive ability levels as against their competitors, possess rare resources.

\subsubsection{Inimitable}

It is apparent that the firm with 'Valuable' and 'Rare' resources will be placed to gain a competitive advantage (Barney 1995, 2001a, 2001b, 2001c; Barney et al. 2011). However, that competitive advantage can only be sustained in the long term if for example competing petroleum companies cannot acquire the same valuable and rare resource(s). In other words, it should be difficult for other firms to copy, replicate or duplicate (Barney 1991). Human resources (people) can serve as an example of inimitability. For example, although a petroleum company with a large talent pool of employees may possess rare resources, competitors may be able to create their own pool of equally able employees. However, such human resources in this instance become imitable under three conditions.

The first is 'Unique historical conditions'. An understanding of the idiosyncratic nature of the attributes of an organization is important to have an imperfectly imitable resource, and the ability of the firm to exploit and acquire resources will depend on their place in time. Academic literature suggest that such performance does not only depend on the economic industry structure at a particular point in time, but also on the path from past history, and how the organization reached this point in time. Therefore, when an organization obtains valuable and rare resources because of its unique path in history, it will be better able to exploit those resources, which cannot be duplicated by other competitors. 
History thus affects all types of resources and makes them more imperfectly imitable. The second element leading to imperfectly imitable resources is 'Causal ambiguity'. This implies that the relationship between the resources controlled by an organization and the source of competitive advantage is not always understood either by the controlling organization, or by other competing organizations (Kull et al. 2016). If that relationship is fully understood by the controlling organization, then it is just a matter of time before others will understand it. The third element leading to imperfectly imitable resources is 'Social complexity'. A resource can be imperfectly imitable if it is a socially complex phenomenon, and if the organization cannot manage or influence it in a systematic way (Barney 1991). This makes it difficult for other firms to imitate. Examples of socially complex resources are the interpersonal relationships between managers. Bingham and Eisenhardt (2008) opines that inimitability represents the most significant resource attribute for competitive advantage.

\subsubsection{Organizational support}

When the resource cannot be replaced by another one that gives same result then that resource can be deemed 'non-substitutable' (Bowman and Ambrosini 2003). As discussed above, the 'Substitutability' characteristic (the ability of competitors to substitute resources) was adjusted in Barney (1995) and replaced by 'Organizational support characteristics'. This fourth characteristic completed the VIRO framework ('Valuable', 'Imitable', 'Rare' and 'Organizational support') (Barney 1995, 1998, 2002). Organization support means that the firm must be organized to exploit its capabilities and resources in order to gain the competitive advantage (Mathur et al. 2014).

\subsection{Critique of RBV theory}


We acknowledge that there is a large body of literature that has criticized RBV theory of which the recent ones include Nason and Wiklund (2015), Bromiley and Rau (2016) and Hitt et al. (2016a). One of the main criticisms of RBV theory is that it appears tautological. Priem and Butler (2001a) opined that the theory advances statements with true and valid definitions, but also that those statements cannot be tested. This has led some scholars, such as Kraaijenbrink et al.'s (2010) to claim that RBV theory cannot meet the criteria for a real theory (Hitt et al. 2016a disagrees with this). The reality however is that although the RBV is difficult to test, a number of studies have been undertaken, which measure resource heterogeneity and performance (see Ketchen and Bergh 2004; Molloy et al. 2011). Other criticisms of RBV theory is that its fundamental constructs are generally applied without any clear distinction between resources and capabilities (Leiblein 2011) and that its focus is almost exclusively internal (Priem and Butler 2001a), despite the reality that understanding operations requires examining not only its internal environment, but also its external environment and the customer context (Bitran and Lojo 1993; Ojiako et al. 2013). Interestingly, critique of RBV theory was an explicit topic of interest published as part of a specific exchange of ideas in 2016 (see Bromiley and Rau 2016; Hitt et al. 2016a,2016b; Ketokivi 2016), the main emphasis of this forum being to advance points and counterpoints as opposing views on whether the resource based view was a useful theory within the operations management discipline. Among the main criticisms of RBV theory highlighted within this forum in addition to measurement validity and conceptual clarity concerns (see Hitt et al. 2016a), as the views expressed by Bromiley and Rau (2016) who argued that RBV theory may not be fit to be used in operations management (and by extension, project management) for three reasons. First, they point out that emphasis on sustained competitive advantage ignores the reality of not only performance variations between 
various organizations, but also the reality that only very few firms actually do sustain competitive advantage. Second, they point out that sustained competitive advantage can be enacted across all levels of an organization meaning that it does not need to be directly transformed into the 'operations level'. Third, the reality that RBV resources maintain VIRO attributes creates measurement challenges, which means that their true value cannot be independently established.

\section{Application of RBV theory}

\subsection{RBV theory and the organization}

The literature suggests that organizations can be conceptualized from four different levels, which we refer to in increasing hierarchy as (i) the 'individual level' (ii) the 'project level' (iii) the 'operations level' (iv) the 'strategic level' and/or 'institutional level'. By 'levels', we refer to "...the hierarchical relationship and attributes of the constituent elements of an organization" (Rousseau 1985, pp. 3 - 4).

At the lowest level of this hierarchy is the 'individual level'. Drawing from the literature (Petro et al. 2019, 2020), from a resource perspective, this level is particularly concerned with decisions of specific practitioners/managers. More specifically, the 'individual level' is interested in how specific actors are able to acquire, mobilize, organize, integrate, develop, re-arrange, manage and deploy the entire spectrum of an organizations assets, competencies and capabilities in a manner that is able to ensure project performance and cope with changes in the business and competitive environment in a manner that ensures competitive advantage. Aligned to this is the view that project performance is to an extent driven by the behavior and decisions of individual stakeholders such as clients (Lim and Ling 2002; Ojiako et al. 2015; Chipulu et al. 2019) and project 
managers (Turner and Müller 2005; Dvir et al. 2006; Müller and Turner 2007; Malach-Pines et al. 2009; Ojiako et al. 2015; Chipulu et al. 2019; Akkermans et al. 2020).

Next is the 'project level'. Reference to 'project level' implies scope of activities undertaken during within projects. It is at this level that strategy is orchestrated (Chipulu et al. 2016; Kopmann et al. 2017; Maylor et al. 2018; Midler et al. 2019) and value created by organizations (Parvan et al. 2015). Projects are the ideal means of delivering strategies in that they are the primary conduit for acquiring, integrating, developing, re-arranging and deploying the entire spectrum of an organizations assets, competencies and capabilities (Narayanan and DeFillippi 2012, Turner and Lee-Kelley 2013; Turner et al. 2015; Petro et al. 2019, 2020). The relationship between the 'project level' and the 'strategic level' is best articulated by Longman and Mullins (2004) who state that "...any strategy session that is worth its salt ultimately distils vision [statements] into critical business issues, and if the organization is really serious, these issues get distilled into projects" (p. 54). Most if not all projects will involve cross-functional, multi-disciplinary and heterogeneous teams, which are temporary and ephemeral in nature (Scott-Young and Samson 2008, 2009). Projects are however under considerable pressures due to resource constraints and the reality that project managers have minimum if not no control over most members of the project delivery team. This comes about because decisions on the utilization of resources are primarily taken and enacted at a higher level than the project despite the reality that any accrued benefit from resources can only be realized by its very use at the level of individual projects (Morris and Geraldi 2011) and supported by specific project management methodologies and processes (Mathur et al. 2013). Projects have become the prevalent means of organizing firm operations (see Jensen et al. 2016; Schoper et al. 2018). Davies and 
Brady (2000) focus on how projects have shifted from the delivery of one-off requirements to become operational “...economies of repetition" (p. 931).

The 'operations level' is the level at which "...the necessary platform for resources common to the strategic and project level to be shared" (Petro et al. 2019; p. 9). Interestingly, Morris and Geraldi (2011) combines the project and operations level into one category - named the 'technical level', which they espouse as being primarily focused on output and outcome delivery. Cooper and Budd (2007) however refer to this category as 'project operations'. They state that “...project operations are responsible for fulfilling customer expectations with respect to project success criteria, setting up the company for repeat business, and enhanced performance reputation" (p. 175). The idea of "project operations' was taken forward by Al-Mazrouie et al. (2020) in the form of an extended project life-cycle. However, they highlight the potential for 'disastrous openings' of such projects due to the discontinuities that exist between the 'project' and 'operations' stage of such endeavors.

It is at the 'strategic level' that an organization seeks to develop the novelty and leverage opportunities required for creating competitive advantage (however, such novelty and opportunities can only be utilized at the project level using appropriate project management processes). Majority if not all decisions on the utilization of resources are primarily enacted at strategic level (through portfolios - see Meskendahl 2010; Martinsuo 2013; Kopmann et al. 2017), although its realization occurs at the project level (Petro et al. 2019). Morris and Geraldi (2011) observes that it is at this level that the conditions for supporting projects (both those with internal focus and those with an external focus are established. Resource leveraging at the strategic level is however susceptible to considerable risks. This risk factor exists because strategic level processes can easily become 
extremely rigid, thus serving as a major risk factor to strategic innovation (see Gagnon 1999).

\subsection{RBV theory in project management literature}

Projects incorporate strategic resources that can provides the umbrella organization a unique position and, accordingly, sustain competitive advantage over its competitors. In effect, the project becomes a source of competitive advantage for the organization. A review of the literature points to a number of studies that have sought to situate RBV theory within project management scholarship (Jugdev 2004; Jugdev et al. 2006, 2007, 2019; Jugdev and Mathur 2006; Mathur et al. 2007, 2013; Killen et al. 2012; Mathur et al. 2013; Govan and Damnjanovic 2016; Perkins et al. 2019). For example, in a series of studies focused on exploring the relationship between project management resources and project performance, Mathur et al. $(2007,2013,2014)$ found evidence to suggests the existence of a relationships between strategic assets (resources) and positive project and firm level performance. Over the years, other studies have followed. These includes Killen et al. (2012) who argued that project management, by itself, can be viewed as a strategic organizational capability which can lead an organization to sustain competitive advantage, Ghapanchi et al. (2014) who sought to identify the necessary resources required for competitive advantage for projects. In sum, the application of RBV theory in project management scholarship is developing, however, it is arguable still not mature, especially in empirical type of research.

\section{Methods}

We show in Figure 1, a roadmap of the research method employed in the study. The roadmap is adapted from Ojiako et al. (2013). The purpose of the research has been 
established as to explore to explore how strategic resources are to be best managed and exploited in order deliver enhanced project performance and sustained business competitiveness; and the Research Question as "What are the strategic resources available in projects and how do these strategic resources provide for enhanced project performance and sustained business competitiveness?".

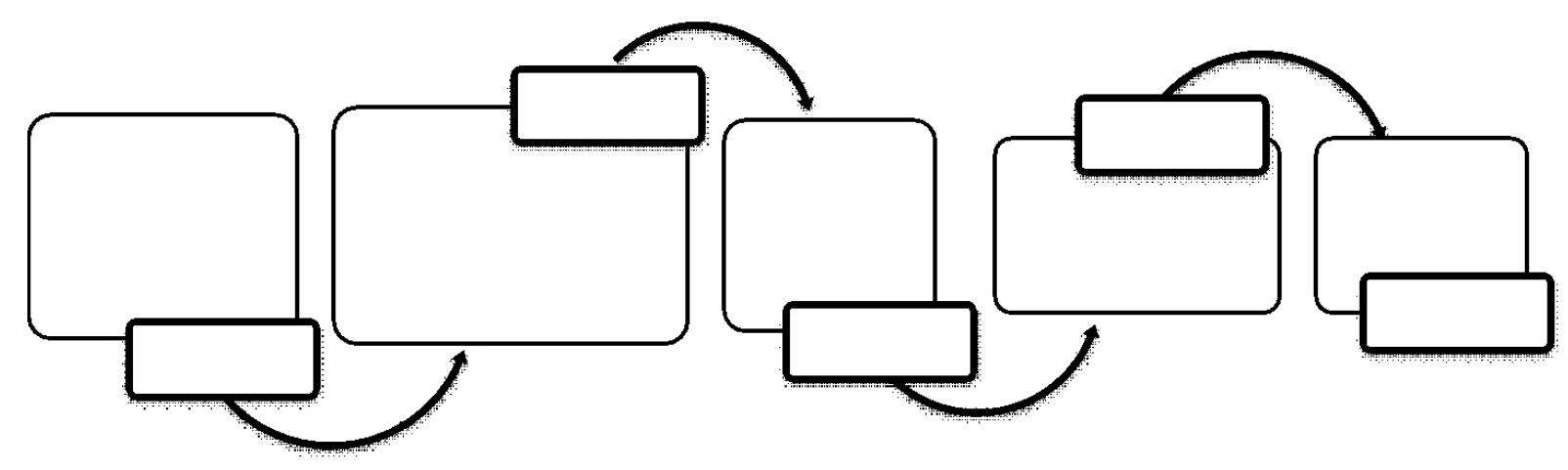

Figure 1: Research roadmap

\subsection{Philosophical stance}

The focus of our study has been on the management and exploitation of resources to enhance project performance and sustenance of businesses operations (a social activity). Boyer and Swink (2008) had earlier observed that, “...the study of operations management is a social science". (p. 339), a view widely shared in project management circles (see Cicmil et al. 2006; Blomquist et al. 2010). For these reasons, our study adopts a philosophical stance, which is consistent with 'social constructivism' (Burr 1995; Adams 2006). At its very 
basic, 'social constructionism' opines that truths are created as against discovered (Burr 1995), that there are thus many truths that all differ based on individual viewpoint of different actors and that these truths are highly influenced by their social context. The implication of this is that a researcher must be disposed to provide explanations for phenomena within a specific context. In our study, this localized context is the petroleum industry.

\subsection{Research approach}

Traditionally, there had been a strong presence and dominance of quantitative approaches in operations management research that has traditionally focused on "...developing a deeper mathematical foundation and understanding" (Fisher 2007, p. 368), through “...mathematical modeling aimed at sharply defined problems" (Narasimhan 2014; p. 201). However, as operations management research has begun to broaden its scope beyond its traditional areas of production efficiency and performance to areas of research including strategic competitiveness, operations management research has increasingly become interested in empirical research of a qualitative nature (see McCutcheon and Meredith 1993; Meredith 1998; Barratt et al. 2011; DeHoratius and Rabinovich 2011; Ketokivi and Choi 2014; Narasimhan 2014; Soltani et al. 2014). The reason being that with its associated emphasis on context, operations management research is increasingly being able to address questions that varyingly focus on 'What is there?', 'What are the key issues', and 'What is happening' - all questions which Handfield and Melnyk (1998; p. 324) opined are best addressed utilizing non-statistical modeling approaches such as interviews. There are three other why the use of qualitative approaches in operations management research is on the increase. First, qualitative approaches represent the best means of understanding the 
dynamics of various inter and intra organizational interfaces. This means that the use of qualitative research approaches is likely to best contribute to the development of operations management theory and practice. Second, the increasing use of qualitative research approaches in operations management research represents a critical means of reinforcing the empirical foundations of the discipline (Soltani et al. 2014). This opinion is also reinforced by Barratt et al. (2011) and Ketokivi and Choi (2014). Third, qualitative approaches appear more suitable for operations management studies that are focused on not only current phenomena (Roth and Rosenzweig 2020), but also the intersection of its various functions (Flynn et al. 1995; Joshi et al. 2003; Pagell 2004; Mahapatra et al. 2010; Parry et al. 2010).

\subsection{The study}

The study consisted of (i) a number of focus groups to ensure the questions were appropriate and were giving useful information and (ii) multiple exploratory semi-structured interviews. For this part of the study, the unit of analysis emphasized the daily decisions of the interviewees as articulated by their daily routines as project management practitioners. The qualitative study allowed us to first, focus us on not only exploring the availability and identification of the strategic project resources, second, to establish how project strategic resources and capabilities provide competitive advantage and sustained competitive advantage, and thirdly, to explore how RBV theory and dynamic capabilities may be best understood at the project level. In Table 3 (below), we show the summary of data collection.

Table 3: Consolidated study approach 


\begin{tabular}{|c|c|c|c|c|c|}
\hline \multicolumn{2}{|c|}{ Data collection phase } & \multirow{2}{*}{$\begin{array}{l}\text { Objective } \\
\text { Addressing the }\end{array}$} & \multirow{2}{*}{$\begin{array}{l}\text { Type of approach } \\
\text { Focus group }\end{array}$} & \multirow{2}{*}{$\begin{array}{c}\text { No. of } \\
\text { Participants } \\
3\end{array}$} & \multirow{2}{*}{$\begin{array}{l}\text { Comments } \\
\text { From one } \\
\text { organization }\end{array}$} \\
\hline Qualitative & $\begin{array}{l}\text { Focus } \\
\text { group }\end{array}$ & & & & \\
\hline & $\begin{array}{l}\text { Main } \\
\text { interview } \\
\text { s }\end{array}$ & $\begin{array}{l}\text { Addressing the } \\
\mathrm{RQ}\end{array}$ & $\begin{array}{l}\text { Semi-structured } \\
\text { interviews }\end{array}$ & 20 & $\begin{array}{l}\text { From different } \\
\text { organizations }\end{array}$ \\
\hline
\end{tabular}

\subsection{The sample}

All data were collected from practitioners associated with project-oriented petroleum organizations in the in the United Arab Emirates and the Sultanate of Oman. As in Chipulu et al. (2014), the participants (interviewees and questionnaire respondents), were identified and recruited to participate in the study through extensive professional networks within both countries by the authors.

To ensure that we did not inadvertently end up with themes, which were unrepresentative, the interviewees were drawn from a mixture of management hierarchies within their organizations (aligned to our earlier delineated organization hierarchy of project, operations and strategic level). Drawing our data from a wide selection of interviewees also allowed for the gathering of valuable insights into RBV theory consequences stemming from the complex project delivery expectations of various stakeholder groups. Based on Marshall et al. (2013), for the single case study, the recommended number of interviews should be between 15 and 30 . We did not glean any further significant in our study after 20 interviews and report only on these.

\subsection{Countries of focus}

Our choice of the United Arab Emirates and the Sultanate of Oman (as to focus on the imperatives of managing strategic resources in petroleum industry projects) comes from the 
strategic role of the petroleum industry in both countries. For example, the Sultanate of Oman has petroleum reserves of about 5.5 billion barrels of oil. In effect, the country currently holds the $25^{\text {th }}$ largest oil reserve in the world. On the other hand, the United Arab Emirates has almost 98 billion barrels of oil reserves (arabianindustry 2019). Both countries are known to commission large projects in the oil and gas area (Al Riyami 2019; Sen 2019). Mindful that our study was not interested in gleaning national cultural cues as had been the case in Chipulu et al. (2014), the entire study was undertaken in English, despite the study being undertaken in the United Arab Emirates and the Sultanate of Oman, two countries where Arabic is the official language. This approach was deemed feasible for despite Arabic being their official language, English is the unofficial business language in both countries.

\subsection{The study}

\subsubsection{Piloting}

The first stage of the qualitative study involved a piloting. We conducted two single interviews and a focus group. A focus group in the form of a group interview was undertaken (Kitzinger 1994; Powell and Single 1996). One advantage of this approach to data gathering is that it has the ability to facilitate increased communication between the participants of a study and in the process, lead to enhanced generation of data, which is relevant (Merton et al. 1956). Kitzinger (1995) opines that focus groups are a very useful means of undertaking research where the focus of such study is to examine "...not only what people think but how they think and why they think that way" (p. 299). Based on the literature, each focus group consisted of six participants. We note that Oates (2000) had recommended between six and ten participants while Halcomb et al. (2007) had recommended that number of focus groups to be undertaken within comparative studies 
was between three and four. Table 4 (below), summarizes the respondents in the pilot qualitative study.

Table 4: Piloting

\begin{tabular}{|c|c|c|c|c|}
\hline Purpose & Position & $\begin{array}{l}\text { Interview } \\
\text { type }\end{array}$ & $\begin{array}{l}\text { \# of } \\
\text { participants }\end{array}$ & Time (mis.) \\
\hline $\begin{array}{l}\text { Addressing } \\
\text { the } R Q\end{array}$ & Project Team Leader & $\begin{array}{l}\text { Semi-structur } \\
\text { ed interview }\end{array}$ & 1 & 41 \\
\hline $\begin{array}{l}\text { Addressing } \\
\text { the } R Q\end{array}$ & Sr. Project Engineers & Focus group & 2 & 113 \\
\hline $\begin{array}{l}\text { Addressing } \\
\text { the RQ }\end{array}$ & $\begin{array}{l}\text { Project Engineering } \\
\text { manager }\end{array}$ & $\begin{array}{l}\text { Semi-structur } \\
\text { ed interview }\end{array}$ & 1 & 43 \\
\hline
\end{tabular}

As per Tables 3 and 4, the total number of focus groups are three: one pilot and two more; and there are a total of twenty interviews.

\subsubsection{The interviews}

We commenced with the qualitative interviews (shown in Table 5).

Table 5: Semi-structured interviewee description

$\begin{array}{llll}\text { Interview } & \text { Interview } & \text { Interviewee Position } & \text { Time (hrs) } \\ \text { no } & \text { code } & & \\ 1 & \text { S.S.I-1 } & \text { Projects commercial officer } & 46 \\ 2 & \text { S.S.I-2 } & \text { General manager - projects } & 77 \\ 3 & \text { S.S.I-3 } & \text { Senior development manager-projects } & 32 \\ 4 & \text { S.S.I-4 } & \text { Senior project manager } & 24 \\ 5 & \text { S.S.I-5 } & \text { General manager operations } & 40 \\ 6 & \text { S.S.I-6 } & \text { General manager maintenance } & 40 \\ 7 & \text { S.S.I-7 } & \text { Projects manager } & 39 \\ 8 & \text { S.S.I-8 } & \text { Project manager } & 37 \\ 9 & \text { S.S.I-9 } & \text { Project construction manager } & 37 \\ 10 & \text { S.S.I-10 } & \text { Development team leader } & 34 \\ 11 & \text { S.S.I-11 } & \text { Project manager } & 30 \\ 12 & \text { S.S.I-12 } & \text { Project manager } & 24 \\ 13 & \text { S.S.I-13 } & \text { Project manager } & 18 \\ 14 & \text { S.S.I-14 } & \text { Project team leader } & 22 \\ 15 & \text { S.S.I-15 } & \text { Project manager } & 43\end{array}$




$\begin{array}{llll}16 & \text { S.S.I-16 } & \text { Operation readiness lead } & 50 \\ 17 & \text { S.S.I-17 } & \text { Project director } & 31 \\ 18 & \text { S.S.I-18 } & \text { Project manager } & 39 \\ 19 & \text { S.S.I-19 } & \text { Project director } & 30 \\ 20 & \text { S.S.I-20 } & \text { Project lead } & 27\end{array}$

The interview protocol employed involved eight questions (Table 6), which were drawn from the RBV literature. More specifically, we designed the questions in a way that could meaningfully surface the individual professional experiences of the interviewees. This stage of the study adopted Kvale's (1994) model of interviewing of which there are seven stages, namely: (i) structuring the questions into themes, (ii) designing, (iii) interviewing, (iv) transcribing, (v) analyzing, (vi) verifying and (vii) reporting. In reporting the interviews, we were particularly mindful that in the words of van Den Hoonaard (2003), "...the onus is on the researcher to acknowledge that the likelihood of tearing the veil of anonymity is a real possibility. To that end, the researcher must incorporate all known devices to maintain anonymity in the research and publication" (p. 149). Bearing this in mind, the authors were particularly mindful of the significant ethical obligation with regard to our ethical obligations not to strip away the veil of anonymity of interviewees (and questionnaire respondents). This is especially as clearly as indicated above; the academic literature does acknowledge that quotes may lead to loss of anonymity. This is because every person can ultimately be identifiable in published research by a "...unique set of expressions and experiences that set him or her off from other human beings" (Van Den Hoonaard 2003; p. 145). It is based on this reason and consideration of the potential failure of our ethical obligations and loss of reputation that we had minimized the use of direct verbatim quotations from the interviewees. 
For the Sultanate of Oman interviews, almost half of the interviewees were drawn from one petroleum organization. There were two reasons. The first is that the organization in question is the largest (and oldest) oil and gas provider in the country. The second reason is that project management practice within the organization is at a very mature state.

Table 6: The interview / focus-group protocols

Question Details

1 Drawing upon your professional experience, what in your opinion are the primary or most important strategic resources (either human; physical; financial or organizational) in your organization?

$2 \quad$ What in your opinion are the attributes that have made these resources valuable?

$3 \quad$ Are these resources rare and if yes, what attributes do you think makes them rare?

$4 \quad$ Are you of the opinion that there is a possibility that any of these resources can be copied by another organization? If yes how and if no, why not?

5 Strategic resources are main factor for:

Organization's project Continuous innovation, Agree? Please elaborate more

Organization's project goal achieving, Agree? Please elaborate more Organization's project cost control, Agree? Please elaborate more Organization's project time control, Agree? Please elaborate more Organization's project quality and expectations, Agree? Please elaborate more

6

At my organization/project, strategic resources are supported by upper management, if you agree please list the ways that your management supported the strategic resources?

7 Compared to other organizations that do the same kind of work, how would you compare the organization's performance in terms of achieving:

\section{Sales targets \\ Profitability levels \\ Market share \\ Customer satisfaction \\ Continuous innovation}

How strategic resources are affecting the organization performance at the project level? Please give all details possible,

\subsubsection{Analysis}

Data analysis was undertaken utilizing NVivo. This provided for a much more robust understanding of various interrelationship and data strings within the study (see Leech and 
Onwuegbuzie 2011). The NVivo analysis commenced with our development (articulation) of parent nodes, which were founded upon individual interview questions. We next created sub-categories against each of these nodes in order to symbolize the primary areas deliberated using terminology employed by the various interviewees. As an example, we first created a node, which was termed 'Currently available strategic resources and capabilities that provide competitive advantage'. Against this, we created sub-topics, which were in effect, sub-questions to the main research questions. For example, against the first node, we created a sub-topic which included 'Definition of strategic valuable resources' and 'Strategic resource that have necessary organizational support'. From the transcribed interview records, the individual responses of each interviewee were then axially coded (see Gorra and Kornilaki 2010) by the first and second. Coding at this stage was undertaken separately. At the point, a theme was identified and then developed via returned forms sent to the third author. A range of standard codes were then agreed upon and applied against all remaining forms. When disagreements ensured, the code to be adopted was made by the third author. Iteratively, we then identified themes that were emerging by establishing links with each topic based on our interpretation of how it related to other topics. In a number of cases, we undertook to reverse specific topics, especially on occasion that on a second reading of a transcript, it was felt that our initial topic was incorrect.

\subsection{The findings}

\subsection{Strategic resource availability in projects}

\subsubsection{Strategic resources availability in projects: the valuable attribute}

Interviewee definitions of 'valuable' ranged from claims that everything was valuable to more specifics, reiterating that project manager, talented employee or visionary leader 
were valuable resources. In between those two answers, almost all agreed that human resources were their number one valuable resource. However, they appeared to have different views on what capabilities that valuable resource should have. A number of the interviewees suggested that resources were always related to the project. A number of the views expressed by the interviewees' suggested that:

"Valuable resources are the ones that brings positive outcome and results when used correctly. And their impact is noticeable"

However, few gave a clear definition on what a valuable resource actually was. Three themes could be seen evolving from the interviews with most of the interviewees pointing to not only human resources as valuable in projects, but also physical and financial resources. Our observation was that however, most interviewees opined that human resources were the most strategic and valuable relied on the idea that, for example, other resources were easier to obtain than human:

"...so, projects can have the needed budget and physical resource but what differentiate one successful project from a failed one is the people."

"Well, if we look around there are not much of strategic resources like human, people are the only force you may call strategic from my point of view, so that comes first, all other resources are actually managed by human to achieve his/her goals"

We however acknowledge that in addition to human resources, there were other resources interviewees reported as valuable. For example, one interviewee pointed out that: "talented humans and the process to develop them", access to financial cash flow from the shareholders, an office, "people, facility, experience, ability of mobilizing resources", and "Culture, the positive environment in the organization and the good relation between the team... Government support, the company and employees feels safe about future".

In Table 7, we show the strategic valuable resources that formed the main themes of the interviewee responses against support for these themes in the literature. 
Tables 7: Strategic valuable resources extracted from interviews

\begin{tabular}{|c|c|c|}
\hline No. & Strategic valuable resources in projects & Example of literatures supporting the findings \\
\hline 1 & $\begin{array}{l}\text { Skilled, talented and capable human resources } \\
\text { that fit the project }\end{array}$ & $\begin{array}{l}\text { Chan et al. (2004), Belout and Gauvreau } \\
\text { (2004), Scott-Young and Samson (2008) and } \\
\text { Ojiako et al. (2008), Zhang et al. (2018) }\end{array}$ \\
\hline 2 & IT application and computation knowledge & Shenhar et al. (2001) \\
\hline 3 & The access to financial cash flow & Laursen and Svejvig, 2016) \\
\hline 4 & $\begin{array}{l}\text { The process to select and develop talented } \\
\text { human resources }\end{array}$ & Kunc and Morecroft (2010) \\
\hline 5 & The ability to exploit resources & Wilden et al. (2018) \\
\hline 6 & $\begin{array}{l}\text { Positive culture that motivates, supports and } \\
\text { keeps human resources }\end{array}$ & Barney et al. (2011) \\
\hline 7 & Project manager/Director/Leader & Jugdev, 2004; Zwikael and Meredith (2018) \\
\hline
\end{tabular}

\subsubsection{Strategic resources availability in projects: the rare attribute}

We then investigated whether 'rare' resources exist, and what could be a good example of such resources in projects. Interviewees' answers had a wide range. Responses can be separated into three main streams. First, some interviewees agreed that rare resources existed and gave real examples; talented project managers, employee development programmes and good cost estimators. Second (the majority), interviewees who agreed with the idea that rare resources existed, but only under certain conditions, such as highly technical staff with particular experience was a very specific area. Third, some interviewees were of the opinion that all necessary resources were available to them and their competitors, and there were actually no rare resources. Table 8 summarizes the rare resources in projects that were cited, in order of the frequency of response.

Table 8: Strategic rare resources in projects 

No. Strategic rare resources in projects
1 Skilled, talented and capable cost estimator that fits the project
$2 \quad$ Well defined project control system, including IT/logistics
3 The way of executing communication
$4 \quad$ The process to select and develop talented human resources
$5 \quad$ Skilled, talented and capable project leader who fits the project

\subsubsection{Strategic resources availability in projects: the inimitable attribute}

According to RBV theory, one of the characteristics of strategic resources is inimitability, the difficulty of competitors in copying a resource. Responses from the interviewees were in two groups: one in which interviewees did not think that there were resources that could be copied, the second either accepted that resources could be copied, albeit only a few, and others were not really sure, or did not give a clear answer in this regard. Some suggested human strategic resources could not be copied, because a good project practitioner (for example) had different skills and experience that made him unique. Three interviewees suggested that it was not possible that that experience could be copied. One interviewee wondered whether the process their organization followed to execute projects was inimitable, and three others shared the exact same view, stating that the method of doing projects in their organization was unique and could not be copied. For one interviewee, the only resource that could be copied was the physical resource, and even that could be executed differently by different parties, so saying "...completely copied" was not accurate. Four interviewees stressed their organization's uniqueness in developing people, meaning that human resources could not be copied (reiterating the notion of inimitability in 
experience). To summarize, Table 9 shows the strategic inimitable resources that emerged from the interviews.

Table 9: Inimitable resources in projects

No. Strategic inimitable resources in projects

1 Skilled, talented and capable human that fits the project

2 The process of tendering and executing projects

3 The process of selecting and developing talented human resources

\subsubsection{Strategic resources availability in projects: the organizational support attribute}

One question raised during the interviews was about the level of support that project resources received from top management. Organizational support is one of the characteristics that strategic resources should have to be a source of competitive advantage. Perhaps not surprisingly, all interviewees suggested that top management support was mandatory for resources. Differences among the interviewees only seemed to appear in terms of the method or type of support.

\subsection{Strategic resources and competitive advantage in projects}

In terms of how strategic resources provided for competitive advantage, responses from the interviewees showed emphasis on human resources providing for strategic use and competitive advantage. For example, an interviewee suggested the very high financial consequences from the absences of strategic resources, namely the right people. However, another, while agreeing, stressed the high impact that a physical resource might have positively or negatively, and gave an example in that regard, in which the scope needed for completion with the necessary quality was due to the presence of the strategic resource. 
We expect that strategic resources will potentially drive sustained competitive advantage for organizations although dependent to an extent on the nature of the business and/or more specifically, operational environment. The interviewees appeared to accept that strategic resources were likely to lead to competitive advantage in projects in that their availability was likely to enhance the projects sense making ability. More specifically, the presence of strategic resources was likely to enhance project control and monitoring capabilities through the de-centralization (which allowed for more flexible and quicker action).

\subsection{Discussion}

The findings do bring to the surface a number of factors which enables us to understand how framed upon the RBV, project-oriented organizations in the petroleum sector are able to manage and exploit their strategic resources for improved project performance and sustenance of businesses operations.

In terms of establishing the strategic resources available in projects, the first resource characteristic we explored was 'Valuable'. The interviewee responses suggest strongly that the valuable resource was a main characteristic of resources considered as strategic. Of these, human resources were the most valuable resources to have in any project. This position is widely acknowledged in academic literature. For example, various studies have identified human and related factors (including project team management) as critical factors for project success (see for example, Chan et al. 2004; Belout and Gauvreau 2004; Scott-Young and Samson 2008; Ojiako et al. 2008; Chipulu et al. 2016, 2019). Interestingly, by the interviewees focusing their discussion on the time, cost and quality factor, it will appear that this notion of project success, while arguably project management 
scholarship has moved beyond (Shenhar et al. 2001; Chipulu et al. 2019), still holds reverence among project management practitioners. Despite this being the case, it is important that we acknowledge that the literature does emphasize that the valuable resource by itself does not necessarily give competitive advantage (Baia et al. 2019). Instead, it is the capabilities of the individual and the organization when used in unique way can exploit the valuable resource, leading to competitive advantage and better project results in this case. Any valuable resource should be combined with capabilities (Ying et al. 2019) and exploited at the right time and phase of a project to bring the expected results, and, in many cases, outstanding performance and innovative ideas.

The second resource characteristic we had explored was 'Rare'. Our findings suggested minimal or no support for the notion of a rareness characteristic being mandatory for strategic resource characteristics. In effect, our findings pointed to a view that there was no such thing as a rare project resource (or even the existence of one did not support a view that it will be so for a long duration). Resource by itself were not necessarily rare in projects, however, some resources when exploited could make an impact on project outcomes. The implication of this finding being that in projects, rareness was not necessarily related to the resource itself. If a resource were to make a significant impact on project outcomes, rareness would relate to the manner within which the resource was being exploited. For these reasons, rareness was mainly related to the process, system and method of project execution as against the specific resources or 'items' utilized in project execution. In effect, what may be important for a project in terms of its strategic resources is the way and manner within which resources are exploited. Rare resource by themselves may not contribute much to project performance. Instead, it is the unique means by which 
resources are exploited that result in rareness, bringing about enhanced project performance, and accordingly competitive advantage (Baia et al. 2019).

The third resource characteristic we had explored was 'Inimitable'. We had earlier pointed to this resource characteristic being of three elements, namely (i) 'Unique historical conditions' (ii) 'Causal ambiguity' and (iii) 'Social complexity'. In effect, the ability of an organization to use and exploit resources will depend (i) on its place in time and space, (ii) on causal ambiguity, meaning that the relationship between the uncopied resource and competitive advantage is not known, and (ii) on the resource creating a socially complex phenomenon, which competing organizations have difficulty in imitating. Interviewees agreed inimitability was another valid characteristic. Majority of the interviewees had construed their resources (especially, human resources), as largely being inimitable, focusing as had been alluded in prior literature (see Ying et al. 2019), on preferred skills, capabilities and tacit knowledge as the determinants of this resource characteristic. In line with prior literature, we had also found that inimitability was not necessarily only a characteristic of the resource in question, but was more or less, a consequence of the 'capabilities' of that specific and/or individual resource (Schoemaker et al. 2018). In effect, reference to a resource being inimitable suggested the need for such an assessment to be undertaken with capabilities in mind (Katkalo et al. 2010). Earlier, we had asserted that dynamic capabilities resources alone cannot bring competitive advantage; likewise, drawing from Ambrosini and Bowman (2009), inimitable capabilities alone are unlikely to automatically provide for 'Effectiveness' and 'Efficiency' in project performance. Such performance we opine will require 'unique exploitation which we construe as meaning that the project resource will have the necessary capabilities and organizational support to be exploited at the right time and for the right purpose. 
The fourth resource characteristic we addressed was 'Organizationally supported'. Drawing from the literature, it will be expected that the organization will provide support in a number of areas including in providing the conducive culture, processes (procedures) and structures (control mechanisms) for its resources to be appropriately exploited (Wiengarten et al. 2013; Bromiley and Rau 2106). Our findings on specific elements of this specific resource characteristic, such as the facilitation of upward communication with top management at critical phases of a project, resonates with project management literature (see for example Mathur et al. 2014; Jugdev et al. 2019). Other findings, including the availability of knowledge- sharing support mechanisms also resonates to available and emerging literature (see Oyemomi et al. 2019). Our findings had suggested that this resource characteristic appeared (among the interviewees) to be the most/particularly significant and important when compared to other strategic resource characteristics.

As relates to how strategic resources providing enhanced project performance and sustained business competitiveness to project-oriented organizations, the interviewees suggested that considerable leveraging of strategic resources could lead to and/or enhance project performance. This is a position shared in the literature (see Jugdev and Mathur 2012). In the project environment, organizational support of strategic resources (both financial and non-financial support) was mandatory for a project to succeed (Mathur et al. 2014), and the ability of an organization to build an innovative environment as part of its support was also needed. However, as noted by the interviewees, strategic resources were only able to provide for enhanced performance and sustained business competitiveness where they are leveraged. Interestingly, the reality that the existence of VIRO attributes within resources is not sufficient to crate enhanced performance and sustained business competitiveness resonates with existing literatures (see Bingham and Eisenhardt 2008; 
Combs et al. 2011; Zollo et al. 2018; Prestes et al. 2019). Instead, such performance and competitiveness stems from a combination of factors which includes (i) an appreciation of VIRO resources, (ii) an appreciation of non-VIRO resources (iii) an understanding of how the underlying characteristics of both VIRO and non-VIRO resources impact upon their relationships and (iv) the ability of the organization to identify, develop, and exploit resource complementarity in a manner that ensures the effective and efficient transfer of resources across various levels of the organization. Often than not, this will also require the organization to focus on the complementarity between strategic resources and non-core resources (Bingham and Eisenhardt 2008). Through complementarity, organizations can obtain competitive advantage by maintaining routines, which are able to support projects much more effectively and efficiently than competitors.

\subsection{Conclusions}

\subsection{Application}

The study which is reported here emerges from a four-year long study (2015-2019) which was undertaken to explore how project-oriented organizations manage and exploit their strategic resources for improved project performance and sustenance of businesses operations (data collection was over a period of approximately three months in 2018). The study had drawn upon RBV theory for theoretical situatedness. Cognizant of our research question, we utilized the VIRO framework ('Valuable', 'Imitable', 'Rare' and 'Organizational support') as our platform for examining strategic resources at the project level.

In sum, the basic premise of our findings as relates to what strategic resources were available in projects is that it will appear that not all elements of the VIRO framework are manifested in petroleum industry projects. Thus, while two characteristics of this 
framework, namely 'Valuable' and 'Organizational support' were manifest, the other two, that is 'Imitable' and 'Rare' did not appear to bear any particular significance to projects. Instead, the findings suggest the emergence of two different characteristics that may be more applicable to projects. That is 'Unique exploitation' and 'Timely availability'. We posit that detailed appreciation of the manifestation of these two new emergent characteristics of strategic resources enhances what should be a much desired for project-oriented organizations to be best placed to manage and exploit their strategic resources for at the very least, improved efficiency and effectiveness in terms of project performance. Conversely, as relates to how strategic resources provided for enhanced project performance and sustained business competitiveness, our findings suggest that leveraging not only relevant VIRO resources, but also the complementarity with non-VIRO resources was essential.

\subsection{Theoretical and practical contributions}

The research made not only theoretical, but also practical contributions to the field of operations and project management. Starting with its contributions to theory, our study extends how RBV theory is understood within operations project management scholarship. As there are limited empirical studies in this area, RBV research especially in project management is still developing. Developing such an understanding is particularly important because as we do know, most projects end up competing for resources, which are controlled at the strategic or institutional level. More specifically, the findings leads us to propose an extension to RBV theory that is specifically relates to the project environment. This proposed extension emphasizes the need for project strategic resources to be 'Valuable' and to be 'Organizationally supported'. 'Rareness' and 'Inimitability' are valid for 
organization level but as per our findings, they are not explicitly embedded to essential for consideration at the project level. Two other characteristics arose from the project environment. Instead as discussed earlier, two other resource characteristic, which we had termed as 'Unique exploitation' and 'Timely availability', have emerged from our study as resource characteristics. Figure 2 (below) is a visual representation of this proposed framework.

Figure 2: Proposed project-based RBV framework

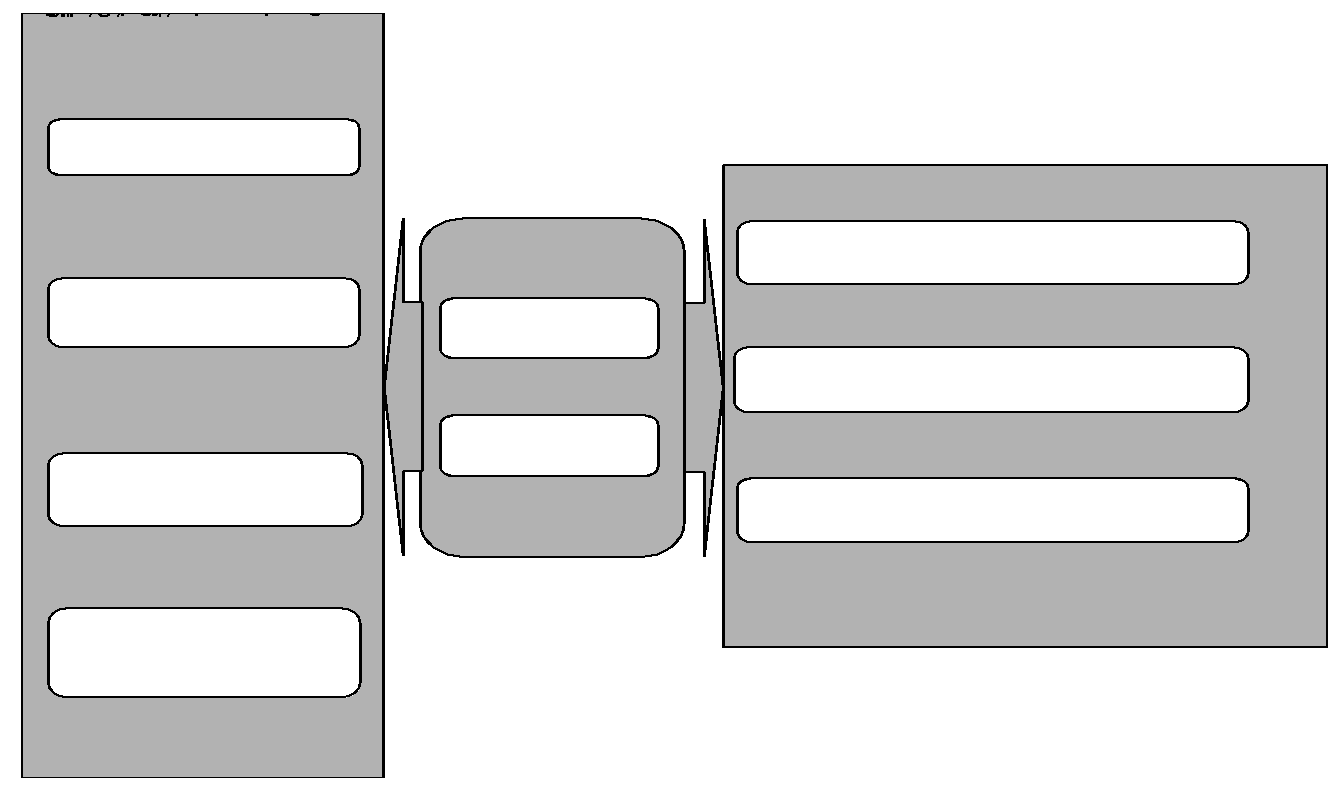

Our contribution to practice gives high-level recommendations for organizations and project practitioners and leaders on the actions needed for better resource utilization. More specifically, the findings provides the basis for developing a practical typology that allows for the management and exploitation of strategic resources for enhanced project performance and sustained business competitiveness that is based on two possible organizing strategies for resource sharing in a manner that ensures that the macro-problem of performance and 
competition filters down the organization. The first will entail alternate sequencing of resources across all levels of the organization in a consecutive and temporal manner. We refer to this approach as 'Resource vacillation' form of organizing (Gulati and Puranam 2009; Boumgarden et al. 2012; Kang et al. 2017). The alternative approach is to seek for parallel and simultaneous switching and sharing of resources across the different organizational levels for a limited and temporal period. This will equate to the idea of 'Resource ambidexterity' (Tushman and O'Reilly 1996; O'Reilly and Tushman 2011, 2013). Exploring both as 'Resource vacillation' and 'Resource ambidexterity' forms of project organizing within emerging project and operational typologies that are boundaryless, virtual, cellular or modular self-managing will be of particular interest to future studies.

\subsection{Limitations}

As perhaps expected, our study does have limitations. For example, as earlier alluded to, we did not take into consideration any cultural cues within RBV theory. Earlier project management scholarship points to national culture serving as a significant driver for heterogeneous perspectives among project stakeholders (Chipulu et al. 2014, 2019). We will accordingly expect that national culture may have an impact upon how individual project managers construe project resources against the VIRO framework ('Valuable', 'Imitable', 'Rare' and 'Organizational support'). For example, we do know that national culture does impact upon 'value' perceptions (Overby et al. 2005). In fact, we do know that national culture does have an impact upon how individuals interpret and respond to strategic issues (Schneider and De Meyer 1991). The same limitation also extends to not taking into consideration project lifecycle variations (Pinto and Prescott 1988), which we do know exists and to which again impacts upon project stakeholder perceptions (Chipulu et al. 2014, 2016, 
2019; Ojiako et al. 2014, 2015). Other limitations include a limited domain of the research

(for example, a focus on project-based organizations within the Arabian Gulf region).

However, despite these limitations, given the reality that the application of RBV theory to project management research is not yet mature, our study makes timely contributions that serves a purpose.

\section{References}

Adams, P. 2006. Exploring social constructivism: Theories and practicalities. Education, 34(3), 243-257.

Akkermans, J., Chipulu, M., Ojiako, U. and Williams, T. 2020. Bridging the fields of Careers and Project Management, 51 (2), 123-134.

Al Riyami, I. 2019. habhab-project. [online] Pdo.co.om. Available online: https://www.pdo.co.om/en/business-with-pdo/Pages/habhab-project.aspx, accessed 30/05/2019.

Al-Mazrouie, J., Ojiako, U., Williams, T., Chipulu, M and Marshall, A. 2020. An operations readiness typology for mitigating against transitional 'disastrous openings' of airport infrastructure projects. Production Planning \& Control, In Press, https://doi.org/10.1080/09537287.2020.1730997.

Ambrosini, V. and Bowman, C. 2009. What are dynamic capabilities and are they a useful construct in strategic management? International Journal of Management Reviews, 11(1), 29-49.

Andersen, O. and Kheam, L. 1998. Resource-based theory and international growth strategies: an exploratory study. International Business Review, 7, 163-184.

arabianindustry. 2019. uae oil reserves - Google Search. [online] Google.com. Available online:

https://www.google.com/search?ei=IR_wXM7gl8bVkwXTmLGoDw\&q=uae+oil+reser ves\&oq=uae+oil+reserves\&gs_l=psyab.3..0l5j0i22i30l5.1503.7329..7582...0.0..0.319. 3138.0j7j5j2.....0....1..gws- wiz......0i71j0i67j0i131i67j0i20i263.HPeEhF8sO0M, accessed 14/05/2019.

Ashrafi, R. and Mueller, J. 2015. Delineating IT resources and capabilities to obtain competitive advantage and improve firm performance. Information Systems Management, 32(1), 15-38.

Baia, E., Ferreira, J. and Rodrigues, R. 2019. Value and rareness of resources and capabilities as sources of competitive advantage and superior performance. Knowledge Management \& \& $\quad$ Practice, DOI: https://doi.org/10.1080/14778238.2019.1599308, 1-14.

Barney, J. 1991. Firm Resources and Sustained Competitive Advantage. Journal of Management, 17(1), 99-120.

Barney, J. 1995. Looking inside for competitive advantage. Academy of Management Perspectives, 9(4), 49-61. 
Barney, J. 1996. The resource-based theory of the firm. Organization science, 7(5), 469-469.

Barney, J. 1999. How a firm's capabilities affect boundary decisions. MIT Sloan Management Review, 40 (3), 137

Barney, J. 2001a. The resource-based view of the firm: Ten years after 1991. Journal of Management, 27(6), 625-641.

Barney, J. 2001b. Resource-based theories of competitive advantage: A ten-year retrospective on the resource-based view. Journal of Management, 27(6), 643-650.

Barney, J. 2001c. Is the resource-based "view" a useful perspective for strategic management research? Yes. Academy of Management Review, 26(1), 41-56.

Barney, J. 2002. Strategic management: From informed conversation to academic discipline. Academy of Management Perspectives, 16 (2), 53-57

Barney, J. 2018. Why resource-based theory's model of profit appropriation must incorporate a stakeholder perspective, Strategic Management Journal, 39 (13), 3305-3325

Barney, J. and Hesterly, W. 2012. Strategic Management and Corporate Competitive Advantage: Concepts, New Jersey: Pearson/Printice Hall.

Barney, J., Ketchen, D. and Wright, M. 2011. The future of resource-based theory: revitalization or decline?. Journal of Management, 37 (5), 1299-1315

Barney, J., Wright, M., \& Ketchen, D. 2001. The resource-based view of the firm: Ten years after 1991. Journal of Management, 27 (6), 625-641

Barney, J. and Zajac, E. 1994. Competitive organizational behavior: toward an organizationally-based theory of competitive advantage. Strategic Management Journal, 15(S1), 5-9.

Barratt, M., Choi, T. and Li, M. 2011. Qualitative case studies in operations management: trends, research outcomes, and future research implications", Journal of Operations Management, 29 (4), 329-342.

Bashir, H., Ojiako, U., Marshall, A., Chipulu, M. and Yousif, A. 2020. The analysis of information flow interdependencies within projects, Production Planning \& Control, DOI: https://doi.org/10.1080/09537287.2020.1821115, In Press.

Belout, A. and Gauvreau, C. 2004. Factors influencing project success: the impact of human resource management. International Journal of Project Management, 22(1), 1-11.

Bingham, C. and Eisenhardt, K. 2008. Position, leverage and opportunity: a typology of strategic logics linking resources with competitive advantage. Managerial and Decision Economics, 29(2-3), 241-256.

Bitran, G. and Lojo, M. 1993. A frame for analyzing service operations. European Management Journal, 11 (3), 271-282.

Blomquist, T., Hällgren, M., Nilsson, A. and Söderholm, A. 2010. Project-as-practice: In search of project management research that matters. Project Management Journal, 41(1), 5-16.

Boumgarden, P., Nickerson, J., and Zenger, T. 2012. Sailing into the wind: Exploring the relationships among ambidexterity, vacillation, and organizational performance. Strategic Management Journal 33(6) 587-610.

Bowman, C. and Ambrosini, V. 2003. How the Resource-based and the Dynamic Capability Views of the Firm Inform Corporate-level Strategy. British Journal of Management, 14(4), 289-303. 
Boyer, K. and Swink, M. 2008. Empirical elephants-why multiple methods are essential to quality research in operations and supply chain management. Journal of Operations Management, 26(3), 338-344.

Bromiley, P. and Rau, D. 2016. Operations management and the resource-based view: Another view. Journal of Operations Management, 41, 95-106.

Bryde, D. 2003. Project management concepts, methods and application", International Journal of Operations \& Production Management, 23 (7), 775-793.

Buffa, E. 1980. Research in operations management. Journal of Operations Management, 1(1), 1-7.

Burr, V. 1995. An Introduction to Social Constructionism, Routledge, London.

Cabrer-Borrás, B. and Rico Belda, P. 2017. Survival of entrepreneurship in Spain. Small Business Economics, 51(1), 265-278.

Chan, A., Scott, D. and Chan, A. 2004. Factors affecting the success of a construction project. ASCE Journal of Construction Engineering and Management, 130(1), 153-155.

Chandrasekaran, A., Linderman, K. and Schroeder, R. 2012. Antecedents to ambidexterity competency in high technology organizations. Journal of Operations Management, 30(1-2), 134-151.

Chipulu, M., Ojiako, U., Gardiner, P., Williams, T., Mota, C., Maguire, S., Shou, Y., Stamati, T. and Marshall, A. 2014. Exploring the impact of cultural values on project performance. International Journal of Operations \& Production Management, 34(3), 364-389.

Chipulu, M., Ojiako, U., Marshall, A., Williams, T., Neoh, J., Mota, C. and Shou, Y. 2016. Building cultural intelligence: insights from project management job advertisements. Production Planning \& Control, 27(3), 133-147.

Chipulu, M., Ojiako, U., Marshall, A., Williams, T., Bititci, U., Mota, C., Shou, Y., Thomas, A., El Dirani, A., Maguire, S. and Stamati, T. 2019. A dimensional analysis of stakeholder assessment of project outcomes, Production Planning \& Control, 30 (13), 1072-1090.

Cicmil, S., Williams, T., Thomas, J. and Hodgson, D. 2006. Rethinking project management: researching the actuality of projects. International Journal of Project Management, 24(8), 675-686

Combs, J., Ketchen, D., Ireland, R. and Webb, J. 2011. The role of resource flexibility in leveraging strategic resources. Journal of Management Studies, 48(5), 1098-1125.

Cooper, M. and Budd, C. 2007. Tying the pieces together: A normative framework for integrating sales and project operations. Industrial Marketing Management, 36(2), 173-182.

Davies, A. and Brady, T. 2000. Organisational capabilities and learning in complex product systems: towards repeatable solutions. Research policy, 29(7-8), 931-953.

De Massis, A., Audretsch, D., Uhlaner, L. and Kammerlander, N. 2017. Innovation with Limited Resources: Management Lessons from the German Mittelstand. Journal of Product Innovation Management, 35(1), 125-146.

DeHoratius, N. and Rabinovich, E. 2011. Field research in operations and supply chain management. Journal of Operations Management, 29 (5), 371-375.

Dvir, D., Sadeh, A. and Malach-Pines, A. 2006. Projects and project managers: The relationship between project managers' personality, project types, and project success. Project Management Journal, 37(5), 36-48. 
Fahy, J. 2000. The resource-based view of the firm: some stumbling-blocks on the road to understanding sustainable competitive advantage. Journal of European industrial Training, 24 (2/3/4), 94-104.

Fernandez, E., Montes, J. and Vazquez, C. 2000. Typology and strategic analysis of intangible resources: a resource-based approach. Technovation, 20, 81-92.

Fisher, M. 2007. Strengthening the empirical base of operations management. Manufacturing \& Service Operations Management, 9 (4), 368-382.

Flynn, B., Sakakibara, S., and Schroeder, R. 1995. Relationship between JIT and TQM: Practices and performance. The Academy of Management Journal, 38(5), 1325-1360.

Foss, N., Klein, P., Kor, Y. and Mahoney, J. 2008. Entrepreneurship, subjectivism, and the resource-based view. Strategic Entrepreneurship Journal, 2, 73-94.

Gagnon, S. 1999. Resource-based competition and the new operations strategy. International Journal of Operations \& Production Management, 19 (2), 125-138.

Galbreath, J. 2005. Which resources matter the most to firm success? An exploratory study of resource-based theory. Technovation, 25(9), 979-987.

Garcia-Parra, M., Simo, P., Sallan, J.M. and Mundet, J. 2009. Intangible liabilities: beyond models of intellectual assets. Management Decision, 47 (5), 819-830.

Ghapanchi, A., Wohlin, C. and Aurum, A. 2014. Resources contributing to gaining competitive advantage for open source software projects: An application of resource-based theory. International Journal of Project Management, 32(1), 139-152.

Gorra, A. and Kornilaki, M. 2010. Grounded theory: experiences of two studies with a focus on axial coding and the use of the NVivo qualitative analysis software. Methodology: Innovative approaches to research, $1 . \quad 30 \quad-\quad 32$. http://eprints.leedsbeckett.ac.uk/957/1/Gorra\%20and\%20Kornilaki.pdf, accessed 24/07/20.

Govan, P. and Damnjanovic, I. 2016. The resource-based view on project risk management. Journal of Construction Engineering and Management, 142(9), p.04016034.

Grant. R. 1991. The Resource-based Theory of Competitive Advantage: Implications for Strategy Formulation. California Management Review, 33, 114-135

Gulati, R. and Puranam, P. 2009. Renewal through reorganiza-tion: the value of inconsistencies between formal and informal organization. Organization Science 20(2), $422-440$.

Halcomb, E., Gholizadeh, L., DiGiacomo, M., Phillips, J. and Davidson, P. 2007. Literature review: considerations in undertaking focus group research with culturally and linguistically diverse groups. Journal of Clinical Nursing, 16(6), 1000-1011.

Hall, R. 1992. The strategic analysis of intangible resources. Strategic Management Journal, 13, 135-144.

Hall, R. 1993. A framework linking intangible resources and capabilities to sustainable competitive advantage. Strategic Management Journal, 14, 607-618.

Handfield, R. and Melnyk, S. 1998. The scientific theory-building process: a primer using the case of TQM. Journal of Operations Management, 16 (4), 321-339.

Hitt, M., Xu, K. and Carnes, C. 2016a. Resource based theory in operations management research. Journal of Operations Management, 41, 77-94. 
Hitt, M., Carnes, C. and Xu, K. 2016b. A current view of resource based theory in operations management: A response to Bromiley and Rau. Journal of Operations Management, 41, 107-109.

Jensen, A., Thuesen, C. and Geraldi, J. 2016. The projectification of everything: Projects as a human condition. Project Management Journal, 47(3), 21-34.

Joshi, M., Kathuria, R. and Porth, S. 2003. Alignment of strategic priorities and performance: an integration of operations and strategic management perspectives. Journal of Operations Management, 21(3), 353-369.

Jugdev, K. 2004. Through the Looking Glass: Examining Theory Development in Project Management with the Resource-Based View Lens. The Project Management Institute, 15-24.

Jugdev, K. and Thomas, J. 2002. Project management maturity models: The silver bullets of competitive advantage?. Project Management Journal, 33(4), 4-14.

Jugdev, K. and Mathur, G. 2006. A factor analysis of tangible and intangible project management assets. Project Management Institute. Paper presented at the 4th Project Management Research Conference, Montreal, QC. July 16- 19, 2006

Jugdev, K., Mathur, G. and Fung, T. 2007. Project management assets and their relationship with the project management capability of the firm. International Journal of Project Management, 25(6), 560-568.

Jugdev, K. and Mathur, G. 2012. Classifying project management resources by complexity and leverage. International Journal of Managing Projects in Business, 5 (1), 105-124.

Jugdev, K., Mathur, G. and Fung, T. 2019. Mediated effect of project management asset characteristics on firm performance. International Journal of Managing Projects in Business, DOI: https://doi.org/10.1108/IJMPB-12-2018-0284, In Press.

Kang, J., Kang, R. and Kim, S. 2017. An empirical examination of vacillation theory. Strategic Management Journal 38(6): 1356-1370.

Katkalo, V., Pitelis, C. and Teece, D. 2010. Introduction: On the nature and scope of dynamic capabilities. Industrial and Corporate Change, 19(4), 1175-1186.

Kavadias, S. 2014. 10-year anniversary of the new product development, R\&D, and project management department in production and operations management-Progress, thoughts, and perspectives. Production and Operations Management, 23(8), 1259-1264;

Ketchen, D. and Bergh, D. 2004. Research methodology in strategy and management. Amsterdam: Elsevier.

Ketokivi, M. and Choi, T. 2014. Renaissance of case research as a scientific method. Journal of Operations Management, 32(5), pp.232-240.

Ketokivi, M. 2016. Point-counterpoint: Resource heterogeneity, performance, and competitive advantage. Journal of Operations Management, 41, 75-76.

Killen, C., Jugdev, K., Drouin, N. and Petit, Y. 2012. Advancing project and portfolio management research: Applying strategic management theories. International Journal of Project Management, 30(5), 525-538.

Kitzinger, J. 1994. The methodology of Focus Groups: the importance of interaction between research participants. Sociology of Health and Illness, 16(1), 103-121.

Kitzinger, J. 1995. Qualitative Research: Introducing focus groups. BMJ, 311(7000), 299-302.

Kopmann, J., Kock, A., Killen, C. and Gemünden, H. 2017. The role of project portfolio management in fostering both deliberate and emergent strategy. International Journal of Project Management, 35(4), 557-570. 
Kraaijenbrink, J., Spender, J. and Groen, A. 2010. The resource-based view: a review and assessment of its critiques. Journal of Management, 36(1), 349-372.

Kristandl, G. and Bontis, N. 2007. Constructing a definition for intangibles using the resource based view of the firm. Management Decision, 45 (9), 1510-1524.

Kull, A., Mena, J. and Korschun, D. 2016. A resource-based view of stakeholder marketing. Journal of Business Research, 69(12), 5553-5560.

Kunc, M. and Morecroft, J. 2010. Managerial decision making and firm performance under a resource-based paradigm. Strategic Management Journal, 31(11), 1164-1182.

Kvale, S. 1994. Ten standard Objections to Qualitative Research Interviews. Journal of Phenomenological Psychology, 25(2), 147-173.

Laursen, M. and Svejvig, P. 2016. Taking stock of project value creation: A structured literature review with future directions for research and practice. International Journal of Project Management, 34(4), 736-747.

Leech, N. and Onwuegbuzie, A. 2011. Beyond constant comparison qualitative data analysis: Using NVivo. School Psychology Quarterly, 26 (1), 70-84.

Leiblein, M. 2011. What do resource- and capability-based theories propose?, Journal of Management, 37 (4), 909-932.

Lev, B. 2007. Intangibles: Management, measurement, and reporting. New York: Brookings Institution.

Lim, E. and Ling, F. 2002. Model for predicting clients' contribution to project success. Engineering Construction and Architectural Management, 9(5-6), 388-395.

Lippman, S. and Rumelt, R. 1982. Uncertain Imitability: An Analysis of Interfirm Differences in Efficiency under Competition. The Bell Journal of Economics, 13(2), 418-438.

Longman, A. and Mullins, J. 2004. Project management: key tool for implementing strategy. Journal of Business Strategy, 25(5), 54-60.

Mahapatra, S., Narasimhan, R., and Barbieri, P. 2010. Strategic interdependence, governance effectiveness and supplier performance: $A$ case study investigation and theory development. Journal of Operations Management, 28(6), 537-552.

Mahoney, J. and Pandian, J. 1992. The resource-based view within the conversation of strategic management. Strategic Management Journal, 13(5), 363-380.

Malach-Pines, A., Dvir, D. and Sadeh, A. 2009. Project manager-project (PM-P) fit and project success. International Journal of Operations \& Production Management, 29 (3), 268-291.

Marshall, B., Cardon, P., Poddar, A. and Fontenot, R. 2013. Does sample size matter in qualitative research?: A review of qualitative interviews in IS research. Journal of Computer Information Systems, 54(1), 11-22.

Marshall, A., Ojiako, U., Wang, V., Lin, F., and Chipulu, M. 2019. Forecasting Unknown/Unknowns by Boosting the Risk Radar within the Risk Intelligent Organisation, International Journal of Forecasting, 35 (2), 644-658.

Martinsuo, M. 2013. Project Portfolio Management in Practice and in Context. International Journal of Project Management 31 (6): 794-803.

Mathur, G., Jugdev, K. and Shing Fung, T. 2007. Intangible project management assets as determinants of competitive advantage. Management Research News, 30(7), 460-475.

Mathur, G., Jugdev, K. and Shing Fung, T. 2013. Project management assets and project management performance outcomes. Management Research Review, 36(2), 112-135. 
Mathur, G., Jugdev, K. and Shing Fung, T. 2014. The relationship between project management process characteristics and performance outcomes. Management Research Review, 37(11), 990-1015.

Maylor, H., Meredith, J., Söderlund, J. and Browning, T. 2018. Old theories, new contexts: extending operations management theories to projects. International Journal of Operations \& Production Management, 38(6), 1274-1288.

McCutcheon, D. and Meredith, J. 1993. Conducting case study research in operations management. Journal of Operations Management, 11 (3), 239-256.

McQue, K. 2020. INTERVIEW: Oman cost-cutting focused on non-producing projects: oil minister. S\&P Global Platts, https://www.spglobal.com/platts/en/market-insights/latest-news/oil/041520-intervi ew-oman-cost-cutting-focused-on-non-producing-projects-oil-minister, accessed $15 / 07 / 20$.

Meredith, J. 1998. Building operations management theory through case and field research. Journal of Operations Management, 16 (4), 441-454.

Merton, R., Fisk, M. and Kendall, P. 1956. The focused interview: A report of the bureau of applied social research. New York: Columbia University.

Meskendahl, S. 2010. The influence of business strategy on project portfolio management and its success-a conceptual framework. International Journal of Project Management 28(8): 807-817.

Midler, C., Maniak, R. and de Campigneulles, T. 2019. Ambidextrous Program Management: The Case of Autonomous Mobility. Project Management Journal p.8756972819869091.

Molloy, J., Chadwick, C., Ployhart, R. and Golden, S. 2011. Making Intangibles "Tangible" in Tests of Resource-Based Theory: A Multidisciplinary Construct Validation Approach. Journal of Management, 37(5), 1496-1518.

Morris, P. and Geraldi, J. 2011. Managing the institutional context for projects. Project Management Journal, 42(6), 20-32.

Müller, R. and Turner, R. 2007. The influence of project managers on project success criteria and project success by type of project. European Management Journal, 25(4), 298-309.

Narasimhan, R. 2014. Theory development in operations management: Extending the frontiers of a mature discipline via qualitative research. Decision Sciences, 45(2), 209-227.

Narayanan, V. K., and R. DeFillippi. 2012. The Influence of Strategic Context on Project Management Systems: A Senior Management Perspective. In Williams, T.M. and Samset, K. (eds) Project governance: Getting Investments Right. Basingstoke, UK: Palgrave Macmillan.

Nason, R. and Wiklund, J. 2015. An Assessment of Resource-Based Theorizing on Firm Growth and Suggestions for the Future. Journal of Management, 44(1), 32-60.

Neely, A., Gregory, M. and Platts, K. 1995. Performance measurement system design: a literature review and research agenda. International Journal of Operations \& Production Management, 15 (4), 80-116.

Newbert, S. 2008. Value, rareness, competitive advantage, and performance: a conceptual-level empirical investigation of the resource-based view of the firm. Strategic Management Journal, 29(7), 745-768. 
O'Reilly, C. and Tushman, M. 2011. Organizational ambidexterity in action: How managers explore and exploit. California Management Review 53(4):5-22.

O’Reilly, C. and Tushman, M. 2013. Organizational ambidexterity: Past, present, and future. Academy of Management Perspectives 27(4): 324-338.

Oates, C. 2000. The Use of Focus Groups in Social Science Research. In Burton, D. Research Training for Social Scientists. London: Sage Publications.

Ojiako, U., Johansen, E. and Greenwood, D. 2008. A qualitative re-construction of project measurement criteria. Industrial Management and Data Systems, 108 (3), 405-417.

Ojiako, U., Maguire, S. and Chipulu, M. 2013. Thematic elements underlying the delivery of services in high-contact public service encounters. Production Planning \& Control, 24(6), 532-545.

Ojiako, U., Chipulu, M., Gardiner, P., Williams, T., Mota, C., Maguire, S., Shou, Y. and Stamati, T. 2014. Effect of project role, age and gender differences on the formation and revision of project decision judgements. International Journal of Project Management 32(4), 556-567.

Ojiako, U., Chipulu, M., Marshall, A., Ashleigh, M., Maguire, S., Williams, T. and Obokoh, L. 2015. Heterogeneity and perception congruence of project outcomes. Production Planning \& Control, 26(11), 858-873.

Otley, D. 2003. Management control and performance management: whence and whither? The British Accounting Review, 35(4), 309-326.

Overby, J., Woodruff, R. and Gardial, S. 2005. The influence of culture upon consumers' desired value perceptions: A research agenda. Marketing Theory, 5(2), 139-163

Oyemomi, O., Liu, S., Neaga, I., Chen, H. and Nakpodia, F. 2019. How cultural impact on knowledge sharing contributes to organizational performance: Using the fsQCA approach. Journal of Business Research, 94, 313-319.

Pagell, M. 2004. Understanding the factors that enable and inhibit the integration of operations, purchasing and logistics. Journal of Operations Management, 22 (5), 459-487.

Parry, G., Mills, J. and Turner, C. 2010. Lean competence: integration of theories in operations management practice. Supply Chain Management: An International Journal, 15 (3), 216-226.

Parvan, K., H. Rahmandad, and A. Haghani. 2015. Inter-Phase Feedbacks in Construction Projects. Journal of Operations Management 39: 48-62.

Penrose, E. 1959. The theory of the growth of the firm. Oxford, UK: Oxford University Press.

Perkins, D., Mathur, G. and Jugdev, K. 2019. Project management resources and outcomes: a confirmatory factor analysis. International Journal of Managing Projects in Business, DOI: https://doi.org/10.1108/IJMPB-07-2019-0170, In Press.

Peteraf, M. and Barney, J. 2003. Unraveling the resource-based tangle. Managerial and Decision Economics, 24(4), 309-323.

Petrick, J., Scherer, R., Brodzinski, J., Quinn, J. and Ainina, M. 1999. Global leadership skills and reputational capital: Intangible resources for sustainable competitive advantage. Academy of Management Perspectives, 13(1), 58-69.

Petro, Y., Ojiako, U., Williams, T., and Marshall, A. 2019. Organizational ambidexterity: a critical review and development of a project focused definition, ASCE Journal of Management in Engineering, 35 (3), 03119001. 
Petro, Y., Ojiako, U., Williams, T., and Marshall, A. 2020. Organizational ambidexterity: using project portfolio management to support project-level ambidexterity, Production Planning \& Control, 31 (4), 287-207.

Petroleum Development Oman. 2017. PDO Sets New Production Record (04/03/17), https://www.pdo.co.om/en/news/press-releases/Pages/PDO\%20Sets\%20New\%20Pr oduction\%20Record.aspx, accessed 17/12/18

Pinto, J. and Prescott, J. 1988. Variations in critical success factors over the stages in the project life cycle. Journal of Management, 14(1), 5-18.

Powell, R. and Single, H. 1996. Methodology matters - V focus groups. International Journal of Quality in Health Care, 18, 499-504.

Prahalad, C. and Hamel, G. 1990. The Core Competence of the Corporation. Harvard Business Review, 68 (3), 79-97.

Prestes Joly, M., Teixeira, J., Patrício, L. and Sangiorgi, D. 2019. Leveraging service design as a multidisciplinary approach to service innovation. Journal of Service Management, 30 (6), 681-715.

Priem, R. and Butler, J. 2001a. Is the resource-based "view" a useful perspective for strategic management research?. Academy of Management Review, 26(1), 22-40.

Priem, R. and Butler, J. 2001b. Tautology in the resource-based view and the implications of externally determined resource value: Further comments. Academy of Management Review, 26(1), 57-66.

Rolstadas, A. 1994. Editorial Project Management. Production Planning \& Control, 5 (1), 1.

Rolstadas, A. 1999. Editorial Management by projects. Production Planning \& Control 10 (1), 1-2.

Roth, A. and Rosenzweig, E. 2020. Advancing Empirical Science in Operations Management Research: A Clarion Call to Action. Manufacturing \& Service Operations Management, 22(1), 179-190.

Rousseau, D. 1985. Issues of level in organizational research: Multilevel and cross-level perspectives. Research in Organizational Behavior, 7, 1-37.

Schneider, S. and De Meyer, A. 1991. Interpreting and responding to strategic issues: The impact of national culture. Strategic Management Journal, 12(4), 307-320.

Schoemaker, P., Heaton, S. and Teece, D. 2018. Innovation, Dynamic Capabilities, and Leadership. California Management Review, 61(1), 15-42.

Schoper, Y.-G., Wald, A., Ingason, H. and Fridgeirsson, T. 2018. Projectification in Western economies: A comparative study of Germany, Norway and Iceland. International Journal of Project Management, 36(1), 71-82.

Scott-Young, C. and Samson, D. 2008. Project success and project team management: Evidence from capital projects in the process industries. Journal of Operations Management, 26(6), 749-766.

Scott-Young, C. and Samson, D. 2009. Team management for fast projects: an empirical study of process industries. International Journal of Operations \& Production Management, 29(6), 612-635.

Sen, I. 2019. Exclusive: Adnoc Onshore forms project management team | MEED. Available online: https://www.meed.com/adnoc-onshore-forms-project-management-team/ [Accessed 30/05/2019].

Shenhar, A., Dvir, D., Levy, O. and Maltz, A. 2001. Project Success: A Multidimensional Strategic Concept. Long Range Planning, 34(6), 699-725. 
Söderlund, J. 2005. Developing project competence: empirical regularities in competitive project operations. International Journal of Innovation Management, 9(04), 451-480.

Soltani, E., K. Ahmed, P., Ying Liao, Y. and U. Anosike, P. 2014. Qualitative middle-range research in operations management: The need for theory-driven empirical inquiry. International Journal of Operations \& Production Management, 34 (8), 1003-1027.

Teece, D., Pisano, G. and Shuen, A. 1997. Dynamic capabilities and strategic management. Strategic Management Journal, 18(7), 509-533.

Teece, D. 1998. Capturing value from knowledge assets: the new economy, markets for know-how, and intangible assets. California Management Review, 40, 55-79.

Turner, N. and Lee-Kelley, L. 2013. Unpacking the theory on ambidexterity: An illustrative case on the managerial architectures, mechanisms and dynamics. Management Learning, 44(2), 179-196.

Turner, J. and Müller, R. 2005. The project manager's leadership style as a success factor on projects: A literature review. Project Management Journal, 36(2), 49-61.

Turner, N., Maylor, H. and Swart, J. 2015. Ambidexterity in projects: An intellectual capital perspective." International Journal of Project Management, 33(1), 177-188.

Tushman, M. and O'Reilly, C. 1996. Ambidextrous organizations: Managing evolutionary and revolutionary change. California Management Review 38, 8 - 30.

van den Hoonaard, W. 2003. Is Anonymity an Artifact in Ethnographic Research?. Journal of Academic Ethics, 1 (2), 141-151.

Wade, M. and Hulland, J. 2004. The resource-based view and information systems research: review, extension, and suggestions for future research. MIS Quarterly, 28 (1), 107-42.

Wang, H., Choi, J., Wan, G. and Dong, J. 2013. Slack Resources and the Rent-Generating Potential of Firm-Specific Knowledge. Journal of Management, 42(2), 500-523.

Warnier, V., Weppe, X. and Lecocq, X. 2013. Extending resource-based theory: considering strategic, ordinary and junk resources. Management Decision, 51 (7), 1359-1379.

Wernerfelt, B. 1984. A resource-based view of the firm. Strategic Management Journal, 5(2), 171-180.

Wiengarten, F., Humphreys, P., Cao, G. and McHugh, M. 2013. Exploring the important role of organizational factors in IT business value: Taking a contingency perspective on the resource-based view. International Journal of Management Reviews, 15(1), 30-46.

Wilden, R., Hohberger, J., Devinney, T. and Lavie, D. 2018. Revisiting James March (1991): Whither exploration and exploitation? Strategic Organization, 16(3), 352-369.

Wright, P., McMahan, G. and McWilliams, A. 1994. Human resources and sustained competitive advantage: a resource-based perspective. International Journal of Human Resource Management, 5(2), 301-326.

$\mathrm{Wu}, \mathrm{L}$. 2007. Entrepreneurial resources, dynamic capabilities and start-up performance of Taiwan's high-tech firms. Journal of Business Research, 60 (5), 549-555.

Ying, Q., Hassan, H. and Ahmad, H. 2019. The Role of a Manager's Intangible Capabilities in Resource Acquisition and Sustainable Competitive Performance. Sustainability, 11(2), 527.

Zhang, Y., Li, J., Jiang, W., Zhang, H., Hu, Y. and Liu, M. 2018. Organizational structure, slack resources and sustainable corporate socially responsible performance. Corporate Social Responsibility and Environmental Management, 25(6), 1099-1107. 
Zimmermann, A., Raisch, S. and Birkinshaw, J. 2015. How is ambidexterity initiated? The emergent charter definition process. Organization Science, 26 (4), 1119-1139

Zollo, M., Minoja, M. and Coda, V. 2018. Toward an integrated theory of strategy. Strategic Management Journal, 39(6), 1753-1778.

Zwikael, O. and Meredith, J. 2018. Who's who in the project zoo? The ten core project roles. International Journal of Operations \& Production Management, 38(2), 474-492.

\section{Appendix A}

Interview Questions:

1. Based on the introduction, what do you think are the strategic resources (either human; physical; financial or organizational) you have in your organization?

2. Are those resources valuable resources and why you think they valuable?

3. Are those resource RARE and if yes why you think they are RARE?

4. Can any one of those resources copied by other organization? If yes how and if no, why not?

5. Strategic resources are main factor for:

- Organization's project Continuous innovation, Agree? Please elaborate more

- Organization's project goal achieving, Agree? Please elaborate more

- Organization's project cost control, Agree? Please elaborate more

- Organization's project time control, Agree? Please elaborate more

- Organization's project quality and expectations, Agree? Please elaborate more

6. At my organization/project, strategic resources are supported by upper management, if you agree please list the ways that your management supported the strategic resources?

7. Compared to other organizations that do the same kind of work, how would you compare the organization's performance in terms of achieving:

- Sales targets

- Profitability levels

- Market share

- Customer satisfaction

- Continuous innovation

8. How strategic resources are affecting the organization performance at project level? Please give all details possible. 